\title{
Capability Building as Potential to Protest Gender and Caste Injustice: Poor Women in Rural India
}

\author{
Mangala Subramaniam ${ }^{1}$
}

Arguing that the Resource Mobilization (RM) approach within social movement theory continues to hold economic and individualistic assumptions, I propose an alternative integrative approach to understand 'capability building' as potential to protest injustices. Drawing from two main streams of literature: the development literature, focusing particularly on the capability building scholarship, and social movement theory, I use sociological insights to explain capability building and develop a capability building model as an alternative to the resource mobilization perspective. Based on data from the Mahila Samakhya Karnataka (MSK) program in India in the form of fieldwork notes and women's group meeting discussions, I apply the capability building model to analyze the experiences of low caste poor women in grassroots groups. Capability building through group sharing of experiences facilitates raising consciousness, developing courage and confidence to be assertive such that women, individually and collectively, protest injustices based on gender and caste. [Article copies available for a fee from The Transformative Studies Institute. E-mail address:_ journal@transformativestudies.org Website: http://www.transformativestudies.org (02009 by The Transformative Studies Institute. All rights reserved.]

KEYWORDS: Resource Mobilization, Capability Building, dalit, Women, India.

\footnotetext{
${ }^{1}$ Mangala Subramaniam, Ph.D., is Associate Professor of Sociology at Purdue University. Her primary areas are gender, social movements including transnational women's movements with secondary interest in research methods. She has authored and co-authored articles in journals such as: Critical Sociology, Mobilization, and Gender \& Society. Her monograph, The Power of Women's Organizing: Gender, Caste, and Class in India (2006) focuses on the women's movement in India with specific attention to dalit women's organizing. Mangala's current research projects focus on socio-cultural scripting in dissemination of information about HIV/AIDS in India and collective resistances to state ownership of water. Address correspondence to: Dr. Mangala Subramaniam, Department of Sociology, Purdue University, 700 West State Street, Stone Hall, West Lafayette, IN 47907; e-mail: mangala@purdue.edu.
}

Acknowledgments: I thank the sangha women who participated in the study. 
"Even a few years back I could not have considered it possible to spend time speaking with other women in a sangha meeting. Between wage labor and housework I did not have the time. And I was not permitted to participate in such activity. Today, our men folk take care of some of the work so that we can attend the sangha meeting” (Sangha woman, Mosabinal Village, Bijapur District).

A sangha refers to a group of anywhere between 10-50 village women in rural Karnataka. The sanghas are formed through a literacy initiative of the Indian government called the Mahila Samakhya Karnataka Program (MSK). "Mahila" means "women" and "Samakhya" is a compound of the Sanskrit words, "sama” meaning "equal", and "akhya" meaning "to be valued or weighed" (Mahila Samakhya Karnataka 1996). Karnataka is a state in southern India. The MSK program of the Department of Education of the Ministry of Human Resource Development is a part of India's Literacy Mission. The program was born out of the emphasis in the New Education Policy of 1986 on education programs that play a positive, interventionist role for women's equality (Government of India Undated a). The program broadens the meaning of 'education' or 'literacy' to encompass learning and social awareness through the mobilization of women's groups (Government of India Undated a). By the end of 1998, the MSK program was working with 25,000 poor women in 1,020 villages in six districts of the state of Karnataka. ${ }^{1}$

The existence and effectiveness of this program seem, at first, to be a validation of a classic view in social movement theory - resource mobilization (RM). The RM approach, initially put forth by McCarthy and Zald (1973), draws from economics and organizational theory to argue that a core task of social movements is organizational and demands the availability of resources in the form of money and personnel/time. By funneling economic support to grassroots women, the MSK program seems to confirm that resources do matter in making movements happen and increasing their odds of success. This is, however, I argue, only a partial explanation. As the quote at the beginning of this paper suggests, the definition of what is possible and the resources that can be made available to a social movement are themselves changeable and negotiable factors. Non-economic factors also play a role in creating opportunities for mobilization and protest. In the case of MSK considered in this paper, two main issues can be identified as significant to the process of change set in motion for poor low caste women. The first is directly 
social: providing poor rural women a supportive organization structure and an opportunity to connect with other women. The second issue is social psychological: building courage and raising the self-confidence of women who have long been silenced through both overt and covert forms of oppression for decades. These processes of changes are evident in individual and collective protests of oppressive structures of gender and caste by MSK's sangha women.

In this paper, I therefore direct attention to understanding processes occurring within groups by extending Amartya Sen's concept of 'capability building' (Sen 1990, 1995, 1997). Capability building views individuals as important in themselves; not just as 'resources' for organizations, and integrates the more cultural and social psychological approaches that have risen in recent years with some of the more fruitful insights of RM (Ferree and Miller 1985; Ferree 1992; Buechler 1993). I draw from two main streams of literature: the capabilities literature and social movement theory to develop a capability building model for protest. The proposed model focuses on the significance of sharing, reflection, and decision-making amongst group members that in turn facilitates building courage and confidence to individually and collectively challenge injustices. The analyses in this paper bring forth the importance of the collective as a resource that poor low caste women draw upon to seek long term social change.

\section{RESOURCES, CAPABILITY BUILDING AND PROTEST}

The RM perspective, a dominant approach in social movement theory, focuses on the criticality of resources for protest movements and considers participants as rational individuals (McCarthy and Zald 1977; Jenkins 1983). This approach has its foundation in economic rationalistic and individual utility arguments to understanding collective action. I situate the resource mobilization perspective within such an economic approach and then elaborate on the critical analysis of such economic based approaches by Amartya Sen who introduces the capabilities approach to understanding well-being (cf. Nussbaum 1995; Sen 1990). I extend the analysis to propose a capability building model to consider processes within groups as significant for individual change and collective action.

\section{Resource Mobilization}

In the 1970s, RM theory emerged as a new approach for the study of social movements positing movements as rational, institutional, and as 


\section{Mangala Subramaniam}

political challenges by aggrieved groups of people. RM theorists have seen social movements as extensions of institutionalized actions and have restricted their focus to movements of institutional change that attempt to alter "elements of social structure and/or the reward distribution of society" (McCarthy and Zald 1977: 1218), organize previously unorganized groups against institutional elites (Gamson 1975) or represent the interests of groups excluded from the polity (Tilly 1978). Several empirical studies affirm the importance of material resources for making social movements possible and support the RM model (Piven and Cloward 1977; Oberschall 1973; Cuzan 1991; Cress and Snow 1996).

RM theory extends the rational actor argument to recruitment and participation in movements and movement organizations. It assumes that individuals are calculative in terms of considering costs and benefits of participation. In the case of public goods, there is a possibility of the free rider dilemma which leads to movement/movement organizations offering selective incentives to participants and withholding it from non participants. This economically based assumption overlooks the moral and purposive basis of peoples' participation in movements (Fireman and Gamson 1979; Ferree 1992; Buechler 1993). The role of non-economic incentives in motivating participation is also significant in the creation of intangible resources.

Several classificatory schemes have been proposed for considering the usefulness of particular resources to control the action of targets (Jenkins 1983; Freeman 1979; Cress and Snow 1996). A scheme relevant to the discussion in this paper is the distinction between tangible resources such as money, facilities and means of communication, and intangible resources. The intangible resources include specialized resources such as organizing and legal skills and the unspecialized labor of supporters (Freeman 1979). But even this recognition of intangible resources does not explain and capture the resources created within an informal group through the sharing of experiences.

As the name implies, RM theory emphasizes the wherewithal for starting, sustaining and expanding social movement organization. Typically, a social movement comprises more than one organization and the organizations are often linked. The more successful organizations, the ones that can mobilize the most resources, tend to be centralized, and formally structured. However, feminist scholars have expanded these early notions of formal structures and have persuasively argued for considering informal and hybrid forms (Staggenborg 1988; Ferree and Martin 1995; Bordt 1997; Purkayastha and Subramaniam 2004). ${ }^{2}$ 
Feminists highlight the importance of the 'means' as well as the ends for change (Martin 1990; Acker 1995; Ferree and Martin 1995). The 'means' refers to the processes occurring within groups to enable raising consciousness of individuals; an aspect I discuss as part of the proposed model.

The above discussion points to some continuing drawbacks in the RM approach. First, the assumption of rationality makes participants seem calculative in their gains. Such an assumption overlooks the social change that can be made possible through participants' struggles against injustices. Second, there is little mention of the different organizational structures as being effective for different tasks. Formal structures provide technical expertise and coordination essential in institutional change efforts but may be less effective in mobilizing participation in grassroots informal groups. Informal organizations are often created by and for the participants who also determine and direct the activities of the organization. Third, little agreement exists on the type of resources that are significant or how they are created. The capability building approach can be useful for addressing some of these concerns.

\section{Capability Building}

Basic education, good health, and human attainments are directly valuable as constituent elements of basic 'capabilities' (Drezè and Sen, 1997; also see Sen, 1997 for a distinction between human capital and human capability). The capabilities approach as a whole is critical of dominant approaches in mainstream economics with their focus on utility construed as satisfaction of preference or desire. Unlike an approach that focuses on the distribution of resources, the capability approach maintains that resources have no value in themselves, apart from their role in promoting human functioning (Sen 1993).

The capability approach to a person's advantage is concerned with evaluating it in terms of his or her actual liberty to achieve various valuable functionings as a part of living. According to Sen (1993), functionings represent parts of the states of a person - in particular the various things that $\mathrm{s} /$ he manages to do or that $\mathrm{s} /$ he would be in leading a life. The capability of a person reflects the alternative combinations of functionings the person can achieve, and from which s/he can choose one collection. The approach is based on a view of living as a combination of various 'doings and beings', with quality of life to be assessed in terms of the capability to achieve valuable functionings. 


\section{Mangala Subramaniam}

Some functionings are very elementary, such as being adequately nourished and/or being in good health and these may be strongly valued by all, for obvious reasons. Others may be more complex, but still widely valued, such as achieving self-respect or being socially integrated. Individuals may, however, differ a good deal from each other in the weights they attach to these different functionings. The functionings relevant for well-being vary from such elementary ones as escaping morbidity and mortality, being adequately nourished, and having mobility to complex ones such as being confident, achieving selfrespect, and taking part in the life of the community.

The ideas of elementary and complex functionings for well-being raise concerns about focusing solely on income (that is class issues) as essential. Secondly, human beings have widely varying needs for resources, and any adequate definition of who is 'better off' and 'worse off' must reflect that fact. Women who have traditionally not been educated, for example, may well require more of the relevant resources to attain the same capability level as others and that is why in the case discussed here for instance, a special literacy program, for poor low caste women was created, rather than a program that distributed resources to all. Thirdly, defining well-being in terms of income or possessions alone, fails to go deep to address the impediments to functioning that are really present in many lives. For example, as we will see below, covert forms of oppression and control operative through a rigid caste system hinder women's ability to articulate and protest individually and/or collectively for change within the family and the community.

The capabilities approach is more nuanced compared to utilitarian and resource based economics approaches for analyzing gender inequality in developing countries and in generating creative proposals for change. However, there is a need to develop a model that relates developing capabilities to challenge and protest injustices to specifically understand the involvement of the community, as a group, in building capabilities. I propose such a model below.

\section{The Model: Capability Building for Protests}

The proposed model identifies three key propositions to explain capability building as potential for protests. The first proposition is the extension of Sen's conceptualization of capability building to achieve valuable functionings to include the institutional and organizational resources as well as collective ideas available for effective action. The second proposition concerns the 'processes' that individuals experience 
within groups; the courage to articulate and share experiences, as well as make decisions. The third proposition suggests a link between the individual and the collective. That is capability building at the individual level has implications for building potential to protest at both the individual level and the collective level. An extension of the definition of capability building directs attention to the very long-term dynamics of social change through collective groups embedded within communities. I extend the concept of building capabilities to include an individual's sense of belonging to a group which is made possible through consciousness-raising.

Consciousness not only provides socially and politically marginalized groups with an understanding of their structural position but establishes new expectations regarding treatment appropriate to their category. Of course, groups can mobilize around a collective consciousness that supports the status quo. Thus, it is only when a group develops an account that challenges dominant understandings that we can use the term oppositional consciousness (Morris 1992). Consciousness-raising provides a "framework for criticizing existing reality and for reinterpreting both one's own past and all history ... Consciousness-raising as a specific political practice is directed toward challenging dominant ideas (i.e. combating the ideological hegemony of male supremacy)" (Ferree and Hess 1985: 175). Development of a consciousness has consequences in terms of the meaning attributed to collective action. Consciousness-raising processes provide women (in the group) the opportunities to reflect, consider options, and make decisions. The process of social transformation involves long-term changes in confidence and courage for individuals. This is also specifically vital for poor low caste women who have little experience with self-assertion. Capability building creates a potential for collective protest for change in social relations, such as caste and gender in the case considered in this paper.

Building capability creates potential for questioning the status quo. Collectively, actors can participate in decision-making to negotiate for benefits, to question the undesirable and unjust status quo, and to protest against injustices. The processes associated with the experiences of the group can, therefore, provide an impetus for long-term social change. The collective ideas generated within the group are resources and result from constantly building capabilities of individuals. These resources are available for effective action based on which the organizational resource that is the collective itself becomes an agent of change.

The proposed capability building model addresses two key concerns surrounding the RM approach by: (1) including a cultural and social 


\section{Mangala Subramaniam}

psychological element in conceptualizing resources and (2) eliminating the solely rational nature of individuals and organizations. By incorporating processes the model explains the 'how' of capability building and is meaningful for those who have internalized the ideas behind the traditional system of discrimination and accept their deprivation as 'natural'. In addition, the individuals and the collective draw on the created resources for protesting injustices. The complex functionings such as building courage, achieving self-respect and taking part in the life of the community are shaped through processes within the collective which in turn builds potential to challenge power.

The proposed model also has implications for the capability building scholarship. The first implication pertains to combining or connecting basic functionings and more complex functionings. Empirical analyses, such as by Moghadam (1994), address basic functionings for capability building assuming that more complex functionings exist. I, however, assert that complex functionings for capability building are a precursor for basic functionings that is evident from the case considered in this paper. The second implication is for incorporating sociological thinking, as attempted in this integrative model, to further extend the capability building scholarship. Let me turn to the context and data and then proceed to apply the proposed model to the case of MSK.

\section{CONTEXT, DATA, AND METHODS}

The MSK Program considered in this paper is a state intervention that emerged in the context of two major developments in India during and after the 1980s: the rise of caste-based organizing and the influence of feminist politics (Subramaniam 2006). With the emergence of castebased parties, dalit men and women began occupying positions of power in the political sphere. ${ }^{3}$ Simultaneously, independent organizing of dalit women, through the National Federation of Dalit Women (NFDW), progressed at an active pace, particularly in urban areas. The growing middle-class women's movement also used protest, lobbying, and partnerships between women's groups and government agencies to create an 'alternative space' in the previously forbidden terrain of government programs. As women's groups attempted to translate feminist constructs into concrete programs of action, there was a shift from looking at power as simply a negative or coercive force to regarding it as a generative, transformative, and productive force as well (Batliwala 1993). The MSK program is one such partnership initiative for promoting poor low caste women's literacy in rural areas in Karnataka. 
Within the state of Karnataka, MSK has sub-units at two levels. For administrative purposes, all states in India are divided into districts, districts are divided into talukas, and several villages comprise a taluka. The district can be seen as the equivalent of the county in states in the U.S. The village is the basic unit. MSK's sub-unit at the district level is called the District Implementation Unit (DIU). The second sub-unit is the sangha at the village level. Several sanghas fall within the purview of a DIU. There is no formal organization at the taluka level, although several clusters of sanghas exist within a taluka. Ten sanghas (around the same area, generally neighboring ones) form a cluster. One sahayogini (the facilitator) is responsible for overseeing ten sanghas that form a cluster (Subramaniam 2006).

The main objective of the MSK program is to mobilize women to form collectives or sanghas at the village level that would be spaces for collective reflection and analysis to enable them recognize their own potential to bring about change in their lives. This idea was not entirely new as it was the basis of some earlier interventions as well. Several 'awareness-generation' programs, such as the Development of Women and Children in Rural Areas (DWCRA), were built around similar analysis of women's situation and the role of education. But these largescale government programs were not entirely successful as they were target-driven and did not provide women the space to share experiences or shape decisions. In the case of MSK, feminist activists and representatives of grassroots NGOs were involved in the discussions for the design of the program. These activists and representatives ensured that the project remained women-centered and that women controlled the processes of change (Government of India undated b). This emphasis is visible in the mobilization efforts and the formation of the sanghas as I note below.

In Karnataka state, a majority of the sangha members are dalits. Dalits are at the bottom of the caste hierarchy. Perceived as a particularly rigid and oppressive form of inequality, the origin of the caste system is a subject of debate. There are four major castes and several sub castes are categorized within a single caste (Dumont 1980). "Caste is and remains essentially, social rank", and the central position of the Brahmans "rests more upon the fact that social rank is determined with reference to them than upon anything else" (Weber 1958: 397). A major characteristic of the caste system is the practice of untouchability through which those from among the lowest caste, especially the Scheduled Castes (SC), are isolated from those belonging to the higher castes to avoid being 'polluted' by contact (Joshi 1986; Beteille 1991). ${ }^{4}$ Living space in 
villages in the study districts is generally structured around caste and religion. The extent of space available to a caste group and the location of households are in relation to the identified central area of the village and both depend on caste. Dalit households are spatially located in the periphery and separate from upper caste households.

More than one-sixth of India's population that is about 160 million people is dalit (meaning 'downtrodden') (Government of India 1999). Some dalits have benefited from India's existing policy of educational and government job quotas. But a majority of dalits continue to live in poverty with little access to opportunities for economic betterment particularly in rural areas. In fact, dalit women struggle against great inequalities at the intersections of class, caste, and gender that shape their experiences. Decades of violence, both overt and covert, against dalit women have impacted their self-esteem and self-confidence as well as trust in others. Such violence serves as a mechanism of control of individual women and of women as a social group. The resulting fear has prevented articulation of experiences by dalit women. It is the assumption of the MSK program that fostering group experiences will be a means for them to recognize oppression and challenge power.

Asymmetry in power relations across castes and gender has important consequences for women from the lower caste in that their exploitation is both specific and simultaneous (Omvedt 1993, 1998). The social relations of caste and gender are based on the exercise of power either through the use of force overtly or in a subtle manner (Kannabiran and Kannabiran 1991; Omvedt 1993, 1998). Dalit women in the sanghas, considered in this paper, experience both overt and covert forms of violence which they have increasingly challenged. The emphasis of the program is for the women themselves to take up the initiative provided by the facilitator to form a collective. The sahayoginis, each of whom oversees approximately ten villages, are the backbone of the MSK program. The sahayogini for each cluster of villages is generally selected from the same group of villages or taluka and is often a woman who herself has faced oppression. The structure of the MSK provides opportunities for the sahayogini to learn, to participate, and connect with other staff as well other individuals and organizations. Sahayoginis, therefore, have the opportunity to rise in the ranks within the organization.

The data for this paper is drawn from fieldwork undertaken between September and December 1998 in four districts, Bidar, Bijapur, Gulbarga, and Raichur, in Karnataka. ${ }^{5}$ While in the field, I attended 11 sangha meetings in the four districts covered in the study and audiotaped the deliberations. In addition, I observed program activities, 
visited several sanghas in the four study districts, and conducted informal interviews with employees of the MSK program. I incorporate this qualitative data below to explain the experiences of the sangha women.

Most sanghas meet once a week, but this schedule is altered depending on the season and the availability of wage labor. Women meet in the village community hall, under a tree, in the front of a temple, or the sangha "mane" (hut). Discussions in meetings cover issues such as violence in families, decisions about contesting elections in the panchayat (local village governance institutions), or possible challenges to caste-based norms such as not touching merchandise before buying it. At the local level, the sangha women set up a savings scheme for themselves and decide on the contribution to be made by each member on a weekly or monthly basis. Sanghas also decide on using the savings amount for extending loans to participants. Fixing interest rates for such loans and monitoring repayment is a responsibility of the sangha. After about 2-3 years of formation sanghas begin to try to find ways to construct their own meeting place, referred to as a sangha 'hut'. Sanghas receive an initial fund from MSK, referred to as the honorarium, about 2-3 years after they are formed which is used as resource for acquisition of land or construction of the 'hut'. Sangha women, who have almost never entered government offices or met government officials before, must use their local institutional base and the courage they have gained through self-development exercises in the sangha to seek land for a "hut." While they receive assistance and information from MSK staff, the decision to seek land allotment from local government institutions rests with the sangha women.

\section{CAPABILITY BUILDING AMONG MSK WOMEN}

In this section, I analyze the experiences of MSK's sangha women using the capability building model to cover individual level capability building and the connection to the collective. I focus on individual capability building as facilitating articulation and self-assertion which results in changes for individual women and at the same time is about strengthening the collective that serves as a resource for mobilization and for protesting injustices.

\section{Individual-level Capability Building: Articulation and Self-Assertion}

Sangha women's ability to articulate, narrate and share experiences is the creation of a resource from capability building. This is significant 


\section{Mangala Subramaniam}

particularly because of the covert forms of control and silencing of dalit women for decades. Overcoming the inhibition to speak does not occur right when a sangha is formed; there is a time lag as women draw on the opportunity to shape change for themselves. Articulation is the first step for change for the sangha women and such expression is the means to seek needs for basic capabilities.

Consider for instance, the meeting at Kanakgeri sangha which was then less than two years old versus the Kulali sangha that was in existence for over five years. I attended a sangha meeting in Kanakgeri, late evening, after the women had returned from agricultural wage labor. The sangha women meet in front of a village temple, an open space. I was accompanied by the sangha facilitator and a staff member from the district office. There were no deliberations whatsoever. Sangha women took quite some time to assemble for a meeting. And, even after they did, there were absolutely no deliberations. In fact, the district staff member who was earlier a sahayogini told me that these experiences were not uncommon. Sangha women found it difficult to even say their names as a way of introducing themselves to the staff member, who only occasionally visits sanghas, and myself. The sangha women did not or could not explain what they had discussed in previous meetings or even suggest what issues they would like to see discussed. While the facilitator posed questions such as, "Would you like to know about the village school council or about nominating a sangha member to contest the elections to the local governance institution?” they evoked no verbal response but only nodding of heads. The Kanakgeri sangha members were yet to make a claim to this space for reflection. This is quite in contrast to the case of Kulali village.

We need to raise money and complete this hall for our meetings. We have some amount from what we raised on the foundation laying day. But we have to quickly decide about visiting the Zilla Panchayat soon (Sangha member).

The above excerpt is drawn from the discussion at a meeting, late one night, at Kulali. I attended this meeting along with the group facilitator and a staff member from the Bijapur district office. While we sat in a dimly lighted partially constructed hall, members began to sing and then among themselves laid out a list of three items they planned to discuss. The facilitator was silently watching and made no move to provide assistance. Sangha women were discussing what they described as an urgent issue-completing the construction of the meeting hall and for which they needed resources. The meeting continued for over an hour and at the end of which they had some options. One of these was to seek 
the honorarium amount that MSK earmarks for sanghas and the second was to visit the district level government office (Zilla Panchayat) and seek allocation of funds. I observed the sangha women were confident about discussing how and where to seek resources from. Similarly, members in Mogadal village actively discussed how to try and get power reconnected for the sangha meeting hall.

These instances of the ability to articulate often involve generating ideas that contribute to decision-making for collective action. The ideas for how to go about seeking a tangible resource such as restoring electric power connection for the meeting hall in Mogadal or seeking government funds for constructing the Kulali meeting hall requires going to a government office and seeking audience with an official. These are difficult propositions to contend with particularly because poor, illiterate dalit women are denied entry into offices or access to officials. But the sangha women have succeeded in gaining access to government offices/officials through the strength and the resource of the collective. The group level articulation, sharing, and reflection facilitate the collective effort to seek resources for individuals too as is evident from the case of the Kulali P.H. sangha.

Women from Kulali P.H. village in Bijapur district, primarily devadasis, are attempting to improve their own lives. ${ }^{6}$ They view the ability to read and write as critical to this concern. One night while visiting another village during my fieldwork I stopped by at Kulali with the district program staff. It was about 9 p.m. on a relatively cold night and women, covering themselves with blankets, were gathering in a small space outside one of the larger homes with small slates and chalks and books. They were getting ready for their nightly lesson they had arranged with two teachers, earlier associated with non-formal education in the district and have volunteered to teach them. Many of the women displayed their skills at reading and writing. Here the sangha serves as a resource to provide an opportunity for the women members, and example for complex functionings being precursors for developing basic capabilities. The collective is a resource for action and at the same time, as we will see below, it has propelled change in the lives of individuals as well.

\section{Individual-level Capability Building: Empowerment and Change}

Sangha women across the four study districts narrated the changes in social relations, particularly gender and caste, they are experiencing within their families and communities. Below I provide two illustrative 
cases; that of Balamma and Hanumavva who challenged and overcame power based on gender and caste.

MSK has been actively engaged in encouraging sangha women to contest panchayat elections. Panchayat is a local governance institution. The 1992, $73^{\text {rd }}$ and $74^{\text {th }}$ amendments to the Indian Constitution require the states of the Indian Union to enforce a local governance structure and provide a one-third reservation of the seats in these elected bodies to women (Subramaniam 2006). Karnataka is one of the first few states in India to enforce a reservation of seats for women in village panchayats.

Balamma, of Hirevalkunta in Raichur district, was elected to the panchayat and cheated of the panchayat President position by some who took advantage of her illiteracy. This incident made her even more determined to learn to read and write. In a short while, she learned to read and write the 52 Kannada letters, then simple words and finally sentences (Kannada is the language spoken in the state of Karnataka). She now signs her name on panchayat notices after reading and understanding the contents. Her ability to read and write has also increased her confidence to participate in panchayat meetings and activities. Her case is typical of how illiteracy was an issue for elected women. Most of the elected women could only sign their names and the possibility of their becoming mere signatories loomed large. Some of the women began trying to learn to read and write from their husband and other male members of their household. But it was not long before the need for programs beyond basic literacy was recognized. MSK decided to begin training in phases. In addition to concentrating on literacy camps, MSK also developed exercises in their training programs to cover details such as the art of public speaking. Balamma's participation in the sangha, I argue, contributed to capability building, particularly her courage to participate in and be involved in formal politics. Moreover, her initiative, along with other sangha women not described here, also partly influenced MSK's organizing of training programs to prepare members to contest panchayat elections and hold office. Balamma's entry into and participation in formal politics, such as in the panchayat, is significant considering the marginalization and restriction of entry of women, and specifically dalit women, into political institutions. This effort challenges the typical gender and caste related barriers to engaging in local formal political institutions. At the same time, as we will see below, sangha women like Hanumavva have also directly protested caste norms and practices.

All the villages covered in this study are structured based on caste and religion. The area in which households or huts belonging to the lowest 
castes are clustered is referred to as the harijankere (the village or area of the harijans). Restrictions on entry into the main area of the village are well understood by the harijans. They may attend the village panchayat meeting in the main village area but would not venture near the households of the upper castes. For instance, Hanumavva of Dotihal village (Raichur district) says that not too long ago she had to stand on the fringes of the village (as a member of the lowest caste) to sell her bundle of firewood. But, now as a member of the sangha and an elected member of the panchayat, she has greater access to the main village areas. By making her way to panchayat meetings through the main village area she questions the power exerted over public space.

\section{Individual-Group Capability Building: Collective Action}

Consideration of individual level capability building is inextricably linked to group processes and the effects of consciousness-raising. Group processes refer to the processes experienced by women within the sanghas such as their involvement in decision-making and collectively protesting the continued perpetuation of caste and gender injustice.

All the sangha women speaking together ... "why should we give in”; “everyone should learn” ... and yelling at each other (Staff member from MSK district office watches the heated discussion in progress after she attempts to interrupt)

The above excerpt is drawn from discussions in a 7 a.m. meeting in Shirdona village in Gulbarga district that I attended. Women discussed the criteria they would use to select which of them would attend a threeweek training program organized through a state-sponsored program. This has implications for learning a new skill (for starting a small scale income generating activity) but it could also mean losing their daily wage labor in the farms as they would be substituted for. The training program offers a stipend to women to make up for the wages lost. However, two of the women who work in the village crèche and receive a monthly salary were also interested in the training as they are sangha members too. Sangha women were concerned that the two crèche employees would receive their salary and a portion of the stipend too. The sangha women discussed and debated the basis for selection of women for the training and did not allow for any intervention by the staff member of the district office. There were bitter arguments among the women. Soon after, they decided that all of the sangha participants 


\section{Mangala Subramaniam}

would attend the training program. Their experiences in the decisionmaking processes were critical to their realization of their own abilities.

The case of the Shirdona sangha meeting is an instance of collective decision-making as specific to this one group. Sanghas or collectives as networks can also serve as resource to challenge or contest power. I discuss two such instances below: the cases of Kallur (Raichur) and Sindagi (Bijapur).

The practices associated with untouchability are also collectively challenged by sangha women as noted in the case of Kallur village. Kallur is a village in Raichur district where dalit women insisted that a local small store-owner should overlook caste differences in catering to customers. The following incident is related to a village local festival which women (from all castes) celebrate by purchasing bracelets from a small store that stocks several varieties of glass bracelets. The owner and workers in the store help the women try on the bracelets. But being from the higher caste they declined to help the dalit (lower caste) women for fear of being "polluted" and being alienated from those in their own, higher castes. While this practice of not helping dalit women has existed for decades, this year the sangha women decided to challenge the practice. They insisted that they be assisted in trying on the bracelets just as was being done for women from the higher castes. When the store owner declined, the women sat before the store refusing to move.

The issue became serious when dalit men joined the women. The differences across caste and challenges to such hierarchies became prominent. I visited the village, late at night, a day after the incident. Intervention by the district administration to restore peace (and, of course, for the dalit women to give in to the practice) failed and police had camped in the village fearing violence. The village women told me that without the sangha they would not have had the courage to challenge this practice. They recognized the significance of the connection they had built with sanghas in neighboring villages. The sangha women and a staff member from the district office discussed enlisting support from the neighboring sanghas. A week later I was told that women from sanghas in the taluka arrived in Kallur to show support. Although, cluster meetings and taluka mahasabhas are organized forums that is regular meetings of the organization, they have provided otherwise secluded women an opportunity to establish connections with the outside world. ${ }^{7}$ This instance emphasizes the caste identity as the Kallur sangha women were supported by dalit men.

Sangha networks were also key actors in another instance related to the murder of a devadasi woman in Sindagi taluka of Bijapur district. In spite 
of efforts by higher caste men to prevent media attention and coverage of the murder the sangha women protested. Women from the sangha of which the devadasi was a member contacted other sanghas and first took out a procession at the taluka level. Then, the women organized a district level procession that culminated at the Bijapur District Commissioner's office (responsible for administration of the district) enlisting support of the sanghas from the other districts in which MSK operates. They squatted in front of this office building until the administration promised to file a case about the murder with the police (Samyukta Karnataka Report 1994). While not completely 'successful' in seeking justice for the murder case, the sangha women sent a message to their immediate world (the taluka, district, and state) about the force they are to reckon with. Although the initiatives of the sangha women were supported by the organization it was up to the sangha to contact and convince women from other village sanghas to participate in the protest. This action supports the argument that the complex functionings such as being happy, achieving self-respect and taking part in the life of the community are shaped through collective level processes which in turn builds potential to challenge power.

The above mentioned instances are indicative of the ability of sangha women to relate to each other, share experiences, and engage in consideration of options available to challenge power structures based on caste as well as gender.

\section{CONCLUSIONS}

In this paper, I integrate two major approaches, the resource mobilization perspective in social movement theory and the capability building approach within the development literature, to propose a model of capability as potential to protest injustices. The proposed model addresses concerns of rationality of individuals in calculation of benefits and the formal structure of organizations for effectiveness that are central to the resource mobilization approach. At the same time, it draws from the idea of the complex functionings of capability building, such as achieving self-respect and taking part in the life of the community, as being shaped through processes within the collective which in turn builds potential to challenge power. This is also made possible through an informal structure of the sangha shaped by the participants.

The existence and effectiveness of the MSK program may at first appear to validate the RM approach. The provision of funds that provided economic support for poor grassroots women do confirm the significance of resources for movements to succeed. But as noted above, 


\section{Mangala Subramaniam}

this is only a partial explanation because resources can be negotiable factors as women in the sanghas. Capability building at the individual level facilitated sangha women's articulation of their life experiences. Such sharing of experiences facilitates consciousness-raising, builds solidarity and creates a resource that sangha members could rely upon to seek tangible needs. The cases of Kulali and Mogadal sanghas show that there is a time lag before women become confident to seek basic capabilities such as power for their meeting hall or teachers to hold literacy classes at night. In both instances, the initiative of the sangha women, rather than the program authorities, was instrumental to collectively seek a resource. Reflection and sharing within groups has also led to individual level challenges.

Sangha women like Balamma and Hanumavva relied on the strength of the group to protest and shift the structure of power on which gender and caste relations are based. Balamma did not turn away from a responsibility to retain the panchayat seat to which she was elected not merely as a president who had to rely on others to read and write but to assert herself and fulfill her responsibilities as the leader of the local governance institution. Her initiative questioned the status quo for dalit women as those elected to panchayats to only fill a quota set out by the government. It broke traditional gender barriers to participation in local political institutions. Similarly, Hanumavva relied on the collective resource to protest the norms of the caste system that structured dalit women's lives by relegating them to the margins of the community both physically and symbolically. Participation in the sangha has brought about change in individual lives, such as of Balamma and Hanumavva, and at the same time opened the possibility for other dalit women to protest the traditional structures of gender and caste that circumscribe their lives.

Being a part of the group, individual women rely on the strength of the collective and are less likely to feel the sense of being "alone." While groups with little experience of collective strength and self-confidence remain vulnerable to manipulation, groups deeply embedded in community life serve as catalysts to bring the power of the mobilized community onto a stage of broader action. Women rework their ideas to seek changes as in the case of Kallur village, Raichur, and the case of the devadasi from Sindagi taluka. In these instances, individual level capability building is inextricably linked to group processes. The power of the group strength is manifest in the collective protests of what the dalit women perceive as caste and gender injustice. 
The analyses in this paper have implications for considering the capability building model in specific contexts or what Purkayastha and Subramaniam (2004) refer to as situated context. Understanding the subtle processes through which collectives and networks (sanghas and network of sanghas) engage in challenging gender and caste norms requires considering the situated context. The case of MSK's sanghas presented here considers the historical and contemporary circumstances in the specific instance to move beyond a generalized description of poor women in a country. This context is placed in the decades of overt and covert form of control that dalit women have experienced which has limited articulation of experiences or challenges to the oppression. It is in such a context that capability building serves as a basis for building confidence and courage and being assertive in protesting and seeking change individually and collectively. Although some scholars acknowledge the significance of the context in analyzing gender relations and activism, much less attempt is made to interpret findings within the context (see Narayan 1997 for a similar argument). The construction of the context at the local level involving a multiplicity of forces such as caste and class, compounds the complexity for tracing change (since the direction and nature of intersection change over time and locale). The complexity frames how change is initiated and/or negotiated by the women. Therefore, what poor women seek to change has to be understood within the context and the conditions women rely on for survival.

\section{ENDNOTES}

${ }^{1}$ In India, the state is divided into districts (similar to a county in the US), districts are divided into talukas and several villages comprise a taluka. The village is the basic unit.

${ }^{2}$ According to Staggenborg (1988), the term, 'informal' is used to describe SMOs that do not adopt a more 'corporate' form. The term 'collectivist' used by Rothschild-Whitt (1979) refers to a specific type of decision-making structure, which is distinct from 'bureaucratic' organizations, but not all informal social movement organizations are collectivist.

${ }^{3}$ Under articles 341 and 342 of the Indian Constitution, certain castes, specified by public notification, have been deemed to be Scheduled Castes (SC). Among the lowest in the caste hierarchy, castes in this category were and are still among the poorest sections of Indian society. 
SCs are also referred to as "Harijan" (a term coined by Gandhi), "untouchables," and "dalits." I use all these terms interchangeably. ${ }^{4}$ See Joshi (1986), Jogdand (1995) for details. “Untouchability,” along with rituals and ritual prohibitions, are an essential feature of the caste system. The practice of untouchability isolates those in the lowest caste, especially the Scheduled Caste, from those belonging to the upper castes. "Untouchables" may not cross the line dividing their part of the village from that occupied by higher castes. They may not use the same wells for drawing water or drink from the same cups as used by others in tea stalls. Although abolished by law, untouchability, as a practice, remains an integral part of daily life in rural India.

${ }^{5}$ The data for this paper is drawn from a larger project that combined quantitative and qualitative methods (cf. Subramaniam 2001; 2006). 6 'Devadasi' is a Sanskrit term that literally means "servant or slave of God.” The devadasi system is a practice prevalent in the Indian subcontinent through which girls (not young boys) are dedicated, before puberty, to the Goddess Yellamma. Being married to a divine force, these women, primarily from among the Scheduled Castes are considered very auspicious since they could never be widowed. Unlike in the $19^{\text {th }}$ century when the devadasis were well-respected, today they are mistresses of local landlords.

${ }^{7}$ Here the term "secluded" refers to the limited interactions with women within the village and with women from other villages.

\section{REFERENCES}

Acker, Joan. 1995. "Feminist Goals and Organizing Processes," in Feminist Organizations: harvest of the new women's movement edited by Myra Marx Ferree and Patricia Yancey Martin. Philadelphia, PA: Temple University Press.

Batliwala, S. 1993. Empowerment of Women in South Asia: Concepts and Practices. New Delhi: FAO-FFHC/AD.

Bordt, Rebacca L. 1997. The Structure of Women's Nonprofit Organizations. Bloomington and Indianapolis: Indiana University Press.

Buechler, Steven M. 1993. Beyond Resource Mobilization? Emerging Trends in Social Movement Theory. The Sociological Quarterly, Volume 34 (2): 217-35.

Cress, Daniel M. and David A. Snow. 1996. "Mobilization at the Margins: Resources, Benefactors, and the Viability of Homeless Social Movement Organizations." American Sociological Review, Vol. 61: 1089-1109.

Cuzán, Alfred G. 1991. "Resource Mobilization and Political Opportunity in the Nicaraguan Revolution: The Praxis.” American Journal of Economics and Sociology, 50(1): 71-83.

Dreze, Jean and Amartya Sen (eds.) 1997. Indian Development. Selected Regional Perspectives. Delhi \& New York: Oxford University Press. 
Dumont, Louis. 1980. Homo Hierarchicus. The Caste System and its Implications. Translated by Mark Sainsbury, Louis Dumont, and Basia Gulati. Chicago: The University of Chicago

Ferree, Myra Marx and Frederick Miller. 1985. "Mobilization and Meaning: Toward an Integration of Social Psychological and Resource Perspectives on Social Movements." Sociological Inquiry 55: 38-61.

Ferree, Myra Marx and Beth Hess. 1985. Controversy and Coalition: The New Feminist Movement. Boston, MA: Twayne.

Ferree, Myra Marx. 1992. "The Political Context of Rationality: Rational Choice Theory and Resource Mobilization,” in Frontiers in Social Movement Theory edited by Aldon D. Morris and Carol McClurg Mueller. New Haven: Yale University Press.

Ferree, Myra Marx and Patricia Yancey Martin (eds). 1995. Feminist Organizations: harvest of the new women's movement. Philadelphia: Temple University Press.

Fireman, Bruce and William Gamson. 1979. "Utilitarian Logic in the Resource Mobilization Perspective" in The Dynamics of Social Movements edited by Mayer N. Zald and John D. McCarthy. Cambridge: Winthrop.

Freeman, Jo (ed.). 1979. Women: A Feminist Perspective. Palo Alto, CA: Mayfield.

Gamson, William. 1975. The Strategy of Social Protest. Homewood, IL: Dorsey Press.

Government of India. 1999. India's Ninth Five-Year Plan. New Delhi: Planning Commission, Government of India.

Government of India. Undated a. Mahila Samakhya. New Delhi: Ministry of Human Resource Development (Department of Education).

Government of India. Undated b. We can change our world. The Mahila Samakhya Karnataka Experience. New Delhi: Ministry of Human Resource Development.

Jogdand, P. G. (ed.) 1995. Dalit Women: Issues and Perspectives. New Delhi, India: Gyan Publishers.

Joshi, Barbara R. 1986. "Introduction” in Untouchable! Voices of the Dalit Liberation Movement edited by Barbara R. Joshi. London: Zed Books.

Jenkins, Craig J. 1983. "Resource Mobilization Theory and the Study of Social Movements.” Annual Review of Sociology 9: 527-53.

Kannabiran, Vasanth and Kalpana Kannabiran. 1991. "Caste and Gender: Understanding Dynamics of Power and Violence.” Economic and Political Weekly 26, no. 37 (September): 2130-33.

McCarthy, J.D. and M. N. Zald. 1973. "Resource Mobilization and Social Movements." American Journal of Sociology 82: 1212-41.

Martin, Patricia Y. 1990. "Rethinking Feminist Organizations.” Gender \& Society 4(2): 182-206

Mahila Samakhya Karnataka. 1996. Beacons in the Dark: A Profile of Mahila Samakhya Karnataka. Bangalore: Mahila Samakhya Karnataka.

McCarthy, John D and Mayer N. Zald. 1977. "Resource Mobilization and Social Movements: A Partial Theory.” American Journal of Sociology 82(6): 1212-41.

Moghadam, Valentine M. 1994. "Building Human Resources and Women’s Capabilities in Afghanistan: A Retrospect and Prospects.” World Development 22 (6): 859-75.

Morris, Aldon. 1992. "Political Consciousness and Collective Action," in Frontiers in Social Movement Theory edited by Aldon D. Morris and Carol McClurg Mueller. New Haven: Yale University Press.

Narayan, Uma. 1997. Dislocating Cultures: Identities, Traditions, and Third World Feminisms. New York, Routledge. 


\section{Mangala Subramaniam}

Nussbaum, Martha C. 1995. "Human Capabilities, Female Human Beings," in Women, Culture and Development: A Study of Human Capabilities edited by Martha C. Nussbaum and Jonathan Glover. Oxford: Clarendon Press.

Oberschall, Anthony. 1973. Social Conflict and Social Movements. Englewood Cliffs, NJ: Prentice- Hall.

Omvedt, Gail. 1993. Reinventing Revolution: New Social Movements and the Socialist Tradition in India. London: East Gate.

Omvedt, Gail. 1998. “The Anti-Caste Movement and the Discourse of Power,” in Region, Religion, Caste, Gender, and Culture in Contemporary India (Volume 3 of the Series on Social Change and Political Discourse in India. Structures of Power, Movements of Resistance) edited by T.V. Sathyamurthy. Delhi: Oxford University Press.

Piven, Frances Fox and Cloward, Richard. 1977. Poor People's Movements. New York: Vintage.

Purkayastha, Bandana and Mangala Subramaniam (eds.) 2004. The Power of Informal Networks: Lessons in Social Change from South Asia and West Africa. Lanham, MD: Lexington Books (imprint of Rowman and Littlefield).

Rothschild-Whitt, J. 1979. "The Collectivist Organization. An Alternative to RationalBureaucratic Models.” American Sociological Review 44: 509-527.

Samyukta Karnataka Report. 1994. "Women’s Protest March.” Samyukta Karnataka, April 22, 1994

Sen, Amartya Kumar. 1997. "Editorial: human capital and human capability." World Development V. 25 no12 (Dec. '97): 1959-61.

Sen, Amartya. 1995. "Gender Inequality and Theories of Justice” in Women, Culture and Development. A Study of Human Capabilities edited by Martha C. Nussbaum and Jonathan Glover. Oxford: Clarendon Press.

Sen, Amartya. 1993. “The Economics of Life and Death.” Scientific American 268 (May): 40-47.

Sen, Amartya. 1990. "Capability and Well-Being," in The Quality of Life edited by Martha Nussbaum and Amartya Sen. Oxford: Oxford University Press.

Staggenborg, Suzanne. 1988. "The Consequences of Professionalization and Formalization in the Pro-choice Movement.” American Sociological Review 53 (August): 585-606.

Subramaniam, Mangala. 2001. Translating participation in informal organizations into empowerment: women in rural India. Ph.D. Dissertation, University of Connecticut, Storrs.

Subramaniam, Mangala, Manjusha Gupte and Debarashmi Mitra. 2003. "Local to Global: Transnational Networks and Indian Women's Grassroots Organizing,” Mobilization, 8(2): 253-70.

Subramaniam, Mangala. 2006. The Power of Women's Organizing: Gender, Caste, and Class in India. Lanham, MD: Lexington Books (sister imprint of Rowman and Littlefield)

Tilly, Charles. 1978. From Mobilization to Revolution. Reading, MA: Addison-Wesley.

Weber, Max. Translated in 1958 by H.H. Gerth and C. Wright Mills. From Max Weber: Essays in Sociology. New York: Oxford University. 